\title{
PENGARUH PENDIDIKAN KEWIRAUSAHAAN DAN LINGKUNGAN KELUARGA TERHADAP MINAT WIRAUSAHA (STUDI KASUS MAHASISWA PERGURUAN TINGGI EKONOMI DI PURWAKARTA)
}

\author{
Iman Sidik Nusannas, SS.,ME \\ STIE DR. KHEZ Muttaqien Purwakarta ${ }^{1)}$ \\ iman.sidik@stiemuttaqien.ac.id
}

\begin{abstract}
This research has the title "The Influence of Entrepreneurship Education and Family Environment on Entrepreneurial Interest (Case Study of College Students of Economics in Purwakarta)" compiled by Iman Sidik Nusannas.

The growing interest in entrepreneurship is determined by many factors. But in this study there are two main factors that are considered to have a major contribution in growing the interest of one's entrepreneurship. In addition, this is strongly influenced by the adequate entry of information about the object of interest. Information on the success of a business raises an understanding to the public that the entrepreneur has a proven prospect of success.

This study aims to examine how the Effect of Entrepreneurship Education and Family Environment on Entrepreneurial Interest (Case Study of Higher Education Economics Students In Purwakarta). Data collection was done through distributing questionnaires addressed to 96 students who had attended entrepreneurship education course by using Accidental sampling technique. To test the hypothesis, there are two tests that are $T$ test (partial), F test (simultaneous) with the help of IBM SPSS software version 23. The results showed that the Entrepreneurship Education and Family Environment has a positive effect on Entrepreneurship Interest among students.
\end{abstract}

Keywords : Entrepreneurship Education, Family Environment, and Interests Entrepreneurship

\section{PENDAHULUAN}

Berwirausaha merupakan salah satu pilihan yang menarik bagi seseorang dalam rangka meniti karir. Karena dengan memilih wirausaha artinya seseorang sudah siap untuk mengeksplor dan memanfaatkan peluang atau sumber daya yang ada sehingga mampu menciptakan inovasi yang baru dalam dunia bisnis. Inovasi bisnis ini akan menjadi sebuah usaha yang memiliki banyak manfaat bagi masyarakat. Manfaat tersebut diantaranya mampu mengurangi pengangguran, meningkatkan pendapatan masyarakat dan menumbuhkan roda perekonomian masyarakat.

Saat ini minat wirausaha menjadi masalah yang sangat menarik. Minat wirausaha yang tinggi seharusnya muncul dalam diri mahasiswa sebagai generasi- generasi ekonom baru, khususnya mahasiswa yang berkonsentrasi di bidang ekonomi. Minat berwirausaha ini seharusnya menjadi cikal bakal nanti untuk mencipatakan usaha baru yang lebih luas. Di tengah keterpurukan kondisi ekonomi saat ini seperti banyaknya penggangguran, kesempatan kerja semakin sulit, dan persaingan di dunia global yang menuntut mahasiswa untuk mampu bersaing. Selain itu lulusan perguruan tinggi setiap tahunnya selalu meningkat yang tidak sebanding dengan peluang kerja.

Untuk mengetahui minat mahasiswa di Purwakarta setelah lulus, penulis melakukan penelitian awal kepada 90 Mahasiswa Perguruan Tinggi Ekonomi 
Tabel 1.1

Minat Mahasiswa setelah lulus dari Perguruan Tinggi

\begin{tabular}{|c|c|c|c|}
\hline $\begin{array}{c}\text { Minat Mahasiswa Setelah } \\
\text { Lulus Perguruan Tinggi }\end{array}$ & $\begin{array}{c}\text { STIE DR. KHEZ } \\
\text { MUTTAQIEN }\end{array}$ & STIE WIKARA & $\begin{array}{c}\text { STIEB PERDANA } \\
\text { MANDIRI }\end{array}$ \\
\hline Pegawai & 20 & 19 & 20 \\
\hline Berwirausaha & 3 & 3 & 5 \\
\hline Melanjutkan S2 & 7 & 8 & 5 \\
\hline Jumlah Mahasiswa & 30 & 30 & 30 \\
\hline Total Mahasiswa & \multicolumn{3}{|c}{90} \\
\hline
\end{tabular}

Sumber : Hasil awal penelitian data diolah

Berdasarkan survey awal terhadap mahasiwa dari ke tiga kampus, diperoleh hasil dari 90 orang mahasiswa yang mengisi kuisioner. Data menunjukan pertama sebanyak 59 responden memilih untuk menjadi pegawai. Ke dua sebanyak 11 responden memilih untuk menjadi wirausaha. Ke tiga sebanyak 20 responden

\section{Tujuan Penelitian}

Adapun yang menjadi tujuan di laksanakan penelitian ini adalah untuk : Untuk mengetahui pengaruh Pendidikan

\section{KAJIAN PUSTAKA}

\section{Pendidikan Kewirausahaan}

Ada banyak sekali ahli yang mendefinisikan mengenai pendidikan kewirausahaan. Mereka memandang dari berbagai sudut pandang. Seperti yang disampaikan oleh Lestari, dkk (2012) dalam Ni Putu dan I Gusti (2016:538) yang menyatakan bahwa pendidikan kewirausahaan dapat membentuk pola pikir, sikap, dan perilaku pada manusia menjadi seorang pengusaha sejati sehingga mendorong mereka untuk memilih wirausaha sebagai karir. Metode pendidikan kewirausahaan bukan hanya mentransfer pengetahuan dan keterampilan melainkan kemampuan untuk menciptakan bisnis nyata (Siswadi, 2013).

\section{Lingkungan Keluarga}

Lingkungan keluarga menurut Lestari et al., (2012) adalah jumlah semua benda hidup dan mati serta seluruh kondisi yang ada didalam kelompok sosial kecil tersebut, yang terdiri atas ayah, ibu dan anak yang mempunyai hubungan sosial memilih untuk melanjutkan ke pasca sarjana. Dari data tersebut diambil dari mahasiswa yang telah mengikuti program studi pendidikan kewirausahaan dari masing-masing perguruan tingginya, hal tersebut menunjukan bahwa minat berwirausaha pada mahasiswa masih rendah

Kewirausahaan dan Lingkungan Keluarga terhadap Minat Wirausaha secara parsial maupun simultan.

Berdasarkan hasil ramuan beberapa ahli, maka merujuk pada Ramussen, dkk (2015), Hensenmark dan Lestari dalam Ni Putu dan I Gusti (2016) ada beberapa dimensi mengenai pendidikan kewirausahan yaitu sebagai berikut : Ability, indikatornya kemapuan menciptakan usaha nyata. Knowledge, indikatornya pengetahuan tentang teknik/cara berwirausaha. Creativity, indikatornya menciptakan usaha dengan ide berbeda. Action, indikatornya perubahan hasil. Personal attitude, indikatornya kemampuan mengatasi keraguan

karena adanya ikatan darah, perkawinan dan atau adopsi. Lingkungan keluarga yang dapat mempengaruhi seseorang untuk menjadi wirausaha dapat dilihat dari segi faktor pekerjaan orang tua. Pekerjaan orang tua sering kali terlihat bahwa ada pengaruh 
dari orang tua yang bekerja sendiri dan memiliki usaha sendiri maka cenderung anaknya akan menjadi pengusaha.

Peran keluarga sangat dominan dalam pembentukan kepribadian anak. Karakter seorang anak akan terbentuk berdasarkan cara keluarga dalam mendidiknya. Menurut Slameto (2010:60-

\section{Minat Wirausaha}

Menurut Mutmainah (2014:33) "minat berwirausaha merupakan dorongan dan keinginan untuk berusaha atau menjalankan suatu bisnis". Minat berwirausaha muncul karena didahului oleh suatu pengetahuan dan informasi mengenai wirausaha yang didapatkan dari lingkungan, kemudian dilanjutkan pada suatu kegiatan partisipasi untuk memperoleh pengalaman, dimana akhirnya muncul keinginan untuk melakukan kegiatan tersebut.

Minat adalah kecenderungan yang menetap dalam subjek untuk merasa tertarik pada bidang tertentu dan merasa senang

\section{METODE PENELITIAN}

Metode yang digunakan adalah metode deskriptip analisis. Tujuan menggunakan metode penelitian ini untuk mengetahui nilai variabel mandiri, baik satu variabel atau lebih (independen) tanpa membuat perbandingan, atau menghubungkan dengan variabel yang lain

\section{HASIL DAN PEMBAHASAN}

\section{Uji Validitas}

Uji validitas digunakan untuk mengukur valid atau tidaknya suatu kuesioner. Suatu kuesioner dikatakan valid jika pertanyaan pada kuesioner mampu untuk mengungkapkan sesuatu yang akan diukur oleh kuesioner tersebut. Untuk mengukur validitas dapat dilakukan dengan menggunakan korelasi antar skor butir pertanyaan dengan total skor konstruk atau variabel (Husein Umar 2010:62).
64) faktor-faktor keluarga yang berpengaruh dalam menentukan keberhasilan anak adalah: Cara orang tua mendidik, relasi antar anggota keluarga, suasana rumah, keadaan ekonomi keluarga, pengertian orang tua, latar belakang kebudayaan.

berkecimpung dalam hal itu (Winkel Widiyatnoto, 2013:5). Menurut Suhartini (2011:44), minat adalah seperangkat mental yang terdiri dari suatu campuran perasaan, harapan, pendirian, kecenderungan yang mengarahkan individu kepada suatu pilihan tertentu. Druker dalam Dedeng (2012:44) mengartikan kewirausahaan dari sisi sifat, watak, dan ciri-ciri yang melekat pada diri seseorang. Ciri tersebut yaitu memiliki kemauan keras untuk mewujudkan gagasan inovatif ke dalam dunia usaha yang nyata dan dapat mengembangkan dengan tangguh.

(Sugiyono 2012:13). Metode survey yang digunakan untuk mendapatkan data dari tempat tertentu dengan cara peneliti melakukan pengumpulan data misalnya membagikan kuisioner dan wawancara terstruktur.
Dasar keputusan yang diambil adalah dengan melihat nilai $\mathrm{r}$ tabel dan $\mathrm{r}$ hitung dengan nilai signifikansi 5\%. Jika nilai $\mathrm{r}$ hitung > $r$ tabel maka instrumen valid dan begitu sebaliknya, jika $r$ hitung $<r$ tabel maka instrumen tidak valid. Untuk menentukan nilai $r$ tabel maka dicari dalam tabel distribusi nilai $r$ tabel dengan signifikansi 5\% dan jumlah sampel (n) 96 . Berikut tabel-tabel ringkasan hasil uji validitas data : 
a) Hasil Uji Validitas Pendidikan Kewirausahaan

Tabel 1.2

Hasil Uji Validitas Pendidikan Kewirausahaan

\begin{tabular}{|c|c|c|c|}
\hline No. Item & r hitung & r tabel 5\% & Keterangan \\
\hline X11 & 0,803 & 0,195 & Valid \\
\hline X12 & 0,811 & 0,195 & Valid \\
\hline X13 & 0,782 & 0,195 & Valid \\
\hline X14 & 0,721 & 0,195 & Valid \\
\hline X15 & 0,696 & 0,195 & Valid \\
\hline
\end{tabular}

Sumber : Data diolah peneliti (2017)

b) Hasil Uji Validitas Lingkungan Keluarga

Tabel 1.2

Hasil Uji Validitas Lingkungan Keluarga

\begin{tabular}{|c|c|c|c|}
\hline No. Item & r hitung & r tabel 5\% & Keterangan \\
\hline X26 & 0,726 & 0,195 & Valid \\
\hline X27 & 0,749 & 0,195 & Valid \\
\hline X28 & 0,802 & 0,195 & Valid \\
\hline X29 & 0,710 & 0,195 & Valid \\
\hline X210 & 0,757 & 0,195 & Valid \\
\hline X211 & 0,624 & 0,195 & Valid \\
\hline
\end{tabular}

Sumber : Data diolah peneliti (2017)

c) Hasil Uji Validitas Minat Berwirausaha

Tabel 1.3

Hasil Uji Validitas Minat Berwirausaha

\begin{tabular}{|c|c|c|c|}
\hline No. Item & r hitung & r tabel 5\% & Keterangan \\
\hline Y12 & 0,665 & 0,195 & Valid \\
\hline Y13 & 0,762 & 0,195 & Valid \\
\hline Y14 & 0,817 & 0,195 & Valid \\
\hline Y15 & 0,750 & 0,195 & Valid \\
\hline Y16 & 0,755 & 0,195 & Valid \\
\hline Y17 & 0,758 & 0,195 & Valid \\
\hline Y18 & 0,710 & 0,195 & Valid \\
\hline
\end{tabular}

Sumber : Data diolah peneliti (2017)

Dari hasil uji validitas di atas menunjukan bahwa semua nilai $r$ hitung $>r$ tabel dengan nilai signifikansi 5\%. Maka

\section{Uji Reliabilitas}

Uji reliabilitas merupakan pengujian yang digunakan untuk mengukur sebuah indikator dari variabel. Setiap pertanyaan item pertanyaan kuesioner dapat dikatakan reliabel jika jawaban yang didapat tetap konsisten atau stabil dari waktu ke waktu (Husein Umar 2010:63). dari itu, semua butir pernyataan dalam kuesioner sebagai instrumen penelitian dianggap valid dan layak untuk digunakan.

Pengujian reliabilitas dapat dilakukan dengan teknik analisis Cronbach Alpha dengan signifikansi alpha (a) 0,05. Teknis analisis ini dibantu dengan software SPSS versi 23. Instrumen dikatakan reliabel jika nilai $\mathrm{r}$ alpha $>0,70$. Berikut tabel hasil uji reliabilitas dari setiap variabel penelitian 
a) Uji Hasil Reliabilitas Pendidikan Kewirausahaan

Tabel 1.4

Uji Hasil Reliabilitas Pendidikan Kewirausahaan

\begin{tabular}{|c|c|c|c|}
\hline No. Item & r alpha & $\begin{array}{c}\text { Standar } \\
\text { Reliabilitas }\end{array}$ & Keterangan \\
\hline X11 & 0,753 & 0,70 & Reliabel \\
\hline X12 & 0,755 & 0,70 & Reliabel \\
\hline X13 & 0,761 & 0,70 & Reliabel \\
\hline X14 & 0,769 & 0,70 & Reliabel \\
\hline X15 & 0,773 & 0,70 & Reliabel \\
\hline
\end{tabular}

Sumber : Data diolah peneliti (2017)

Reliability Statistics

\begin{tabular}{|r|r|}
\hline $\begin{array}{c}\text { Cronbach's } \\
\text { Alpha }\end{array}$ & N of Items \\
\hline, 797 & 6 \\
\hline
\end{tabular}

b) Uji Hasil Reliabilitas Lingkungan Keluarga

Tabel 1.5

Uji Hasil Reliabilitas Lingkungan Keluarga

\begin{tabular}{|c|c|c|c|}
\hline No. Item & $\mathrm{r}$ alpha & $\begin{array}{c}\text { Standar } \\
\text { Reliabilitas }\end{array}$ & Keterangan \\
\hline X26 & 0,752 & 0,70 & Reliabel \\
\hline X27 & 0,753 & 0,70 & Reliabel \\
\hline X28 & 0,745 & 0,70 & Reliabel \\
\hline X29 & 0,750 & 0,70 & Reliabel \\
\hline X210 & 0,748 & 0,70 & Reliabel \\
\hline X211 & 0,764 & 0,70 & Reliabel \\
\hline
\end{tabular}

Sumber : Data diolah peneliti (2017)

Reliability Statistics

\begin{tabular}{|r|r|}
\hline $\begin{array}{c}\text { Cronbach's } \\
\text { Alpha }\end{array}$ & N of Items \\
\hline, 783 & 7 \\
\hline
\end{tabular}

c) Uji Hasil Reliabilitas Minat Berwirausaha

Tabel 1.6

Uji Hasil Reliabilitas Minat Berwirausaha

\begin{tabular}{|c|c|c|c|}
\hline No. Item & r alpha & $\begin{array}{c}\text { Standar } \\
\text { Reliabilitas }\end{array}$ & Keterangan \\
\hline Y12 & 0,761 & 0,70 & Reliabel \\
\hline Y13 & 0,754 & 0,70 & Reliabel \\
\hline Y14 & 0,748 & 0,70 & Reliabel \\
\hline Y15 & 0,759 & 0,70 & Reliabel \\
\hline Y16 & 0,753 & 0,70 & Reliabel \\
\hline Y17 & 0,754 & 0,70 & Reliabel \\
\hline Y18 & 0,759 & 0,70 & Reliabel \\
\hline
\end{tabular}

Sumber : Data diolah peneliti (2017) 
Reliability Statistics

\begin{tabular}{|r|r|}
\hline $\begin{array}{c}\text { Cronbach's } \\
\text { Alpha }\end{array}$ & N of Items \\
\hline, 783 & 8 \\
\hline
\end{tabular}

\section{Uji Normalitas}

\section{Uji Kolmogorov Smirnov}

Uji kolmogorov smirnov ini bertujuan untuk mengetahui penyebaran data dengan menganalisis nilai residual, nilai residual ini mengindikasikan dua hal yaitu, apakah data berdistribusi normal atau

tidak. Dasar keputusannya yaitu dengan melihat nilai signifikansi. Jika nilai signifikansi $>0,05$ maka data berdistribusi normal. Jika nilai signifikansi $<0,05$ maka data tidak berdistribusi normal

Tabel 1.7

Hasil kolmogorov smirnov test

One-Sample Kolmogorov-Smirnov Test

\begin{tabular}{|ll|r|}
\hline & & $\begin{array}{r}\text { Unstandardize } \\
\text { d Residual }\end{array}$ \\
\hline N & & 96 \\
Normal Parameters ${ }^{\mathrm{a}, \mathrm{b}}$ & Mean &, 0000000 \\
& Std. Deviation & 2,60240857 \\
Most Extreme & Absolute &, 057 \\
Differences & Positive &, 055 \\
& Negative &,- 057 \\
Test Statistic & &, 057 \\
Asymp. Sig. (2-tailed) & &, $200^{\mathrm{c}, \mathrm{d}}$ \\
\hline
\end{tabular}

a. Test distribution is Normal.

b. Calculated from data.

c. Lilliefors Significance Correction.

$\mathrm{d}$. This is a lower bound of the true significance.

Sumber : Data diolah peneliti (2017)

Mengacu pada tabel 4.29 mengenai uji normalitas ini maka dapat diketahui bahwa nilai signifikansi hitung 0,200 >0,05. Maka dapat disimpulkan bahwa data ini berdistribusi normal.

\section{Gambar 1.1}

\section{Hasil Histogram}

Histogram

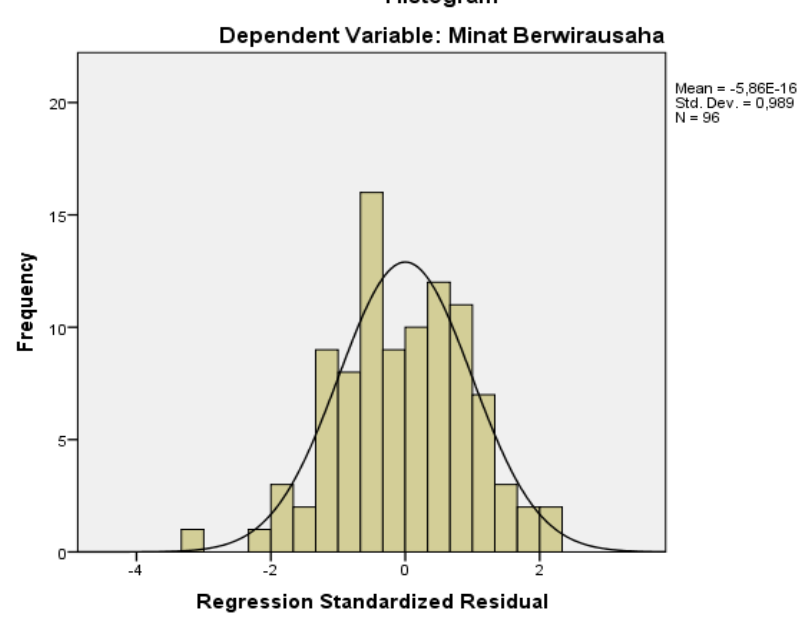


Berdasarkan hasil grafik histogram di atas, dapat diketahui grafik memiliki fluktuasi kurtosis positif (tidak merata). Maka dapat disimpulkan distribusi data ini normal.

\section{Uji Linieritas}

Tabel 1.8

Uji linearitas

Coefficients $^{\mathbf{a}}$

\begin{tabular}{|c|c|c|c|c|c|c|c|c|}
\hline \multirow{2}{*}{\multicolumn{2}{|c|}{ Model }} & \multicolumn{2}{|c|}{$\begin{array}{l}\text { Unstandardized } \\
\text { Coefficients }\end{array}$} & \multirow{2}{*}{$\begin{array}{c}\begin{array}{c}\text { Standardize } \\
\mathrm{d} \\
\text { Coefficients }\end{array} \\
\text { Beta } \\
\end{array}$} & \multirow[b]{2}{*}{$\mathrm{t}$} & \multirow[b]{2}{*}{ Sig. } & \multicolumn{2}{|c|}{$\begin{array}{l}\text { Collinearity } \\
\text { Statistics }\end{array}$} \\
\hline & & B & Std. Error & & & & $\begin{array}{c}\text { Toleranc } \\
\mathrm{e}\end{array}$ & VIF \\
\hline & (Constant) & 10,309 & 2,706 & & 3,810 &, 000 & & \\
\hline & $\begin{array}{l}\text { Pendidikan } \\
\text { Kewirausahaan }\end{array}$ & ,869 & , 118 & ,638 & 7,376 & ,000 & ,817 & 1,224 \\
\hline & $\begin{array}{l}\text { Lingkungan } \\
\text { Keluarga }\end{array}$ & ,052 & 104 & ,043 & 498 & ,620 & ,817 & 1,224 \\
\hline
\end{tabular}

a. Dependent Variable: Minat Berwirausaha

Sumber : Data diolah peneliti (2017)

Dalam pengujian ini untuk melihat keterkaitan antar variabel $\mathrm{X}$, dapat dilihat dari nilai VIF dan Tolerance. Jika nilai VIF > 10 maka terdapat linieritas. Jika nilai tolerance < 10 maka tidak terjadi linieritas. Berdasarkan data di atas dapat diketahui :

a. Nilai VIF 1,224 < 10 maka variabel $\mathrm{X}$ ini tidak memiliki linieritas.

b. Nilai tolerance $0,817<10$ maka variabel $\mathrm{X}$ tidak memiliki linieritas.

\section{Hasil Regresi Berganda}

Tabel 1.9

\section{Hasil regresi berganda}

Coefficients

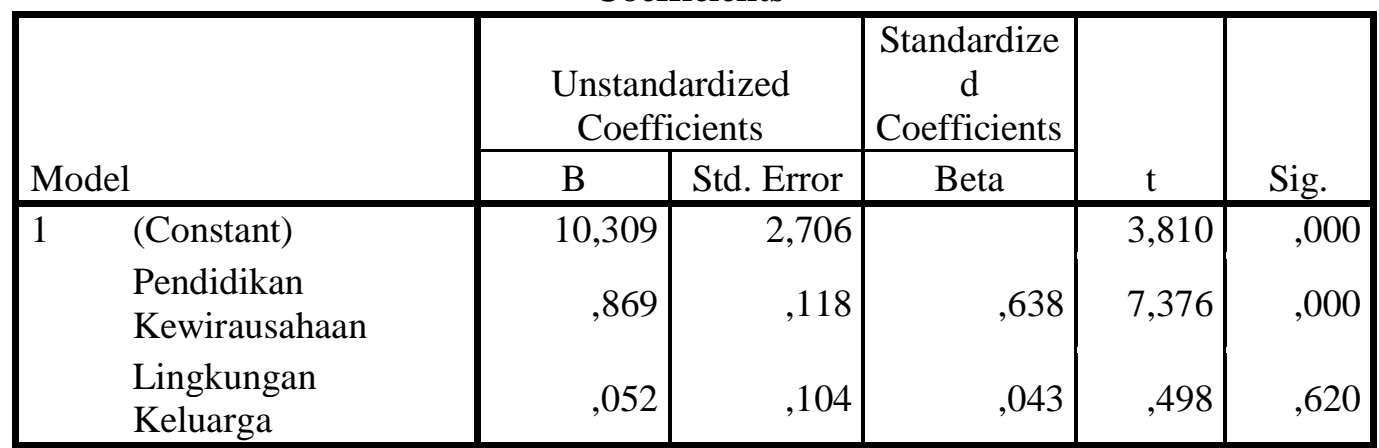

a. Dependent Variable: Minat Berwirausaha

Sumber : Data diolah peneliti (2017)

Mengacu pada tabel di atas maka dapat dibuat persamaan regresi sebagai berikut :

$\mathbf{Y}=10,309+0,869 X_{1}+0,052 X_{2}+e$

Berdasarkan persamaan di atas maka dapat dijelaskan sebagai berikut :

a. Konstanta $\left(\AA_{0}\right)$ memiliki nilai 10,309. Nilai ini menunjukan bahwa jika tidak ada variabel pendidikan kewirausahaan dan lingkungan keluarga maka minat berwirausaha memiliki nilai 10,309 . b. Koefisien $\beta_{1}$ bernilai 0,869 . Nilai ini menunjukan bahwa pengaruh pendidikan kewirausahaan terhadap minat berwirausaha adalah 0,869 . Berdasarkan nilai ini dapat dikatakan pendidikan kewirausahaan memiliki pengaruh yang relatif besar, jika variabel pendidikan kewirausahaan meningkat $1 \%$ maka minat berwirausaha akan meningkat $0,869 \%$. 
c. Koefisien $\square_{2}$ bernilai 0,052 . Nilai ini menunjukan bahwa pengaruh lingkungan keluarga terhadap minat berwirausaha adalah 0,052. Berdasarkan nilai ini dapat dikatakan lingkungan keluarga memiliki pengaruh yang relatif kecil, jika variabel lingkungan keluarga meningkat $1 \%$ maka minat berwirausaha akan meningkat $0,052 \%$.

\section{Uji T}

Tabel 1.10

Hasil Uji T

Coefficients $^{\mathrm{a}}$

\begin{tabular}{|c|c|c|c|c|c|c|}
\hline \multirow{2}{*}{\multicolumn{2}{|c|}{ Model }} & \multicolumn{2}{|c|}{$\begin{array}{l}\text { Unstandardized } \\
\text { Coefficients }\end{array}$} & \multirow{2}{*}{$\begin{array}{c}\begin{array}{c}\text { Standardized } \\
\text { Coefficients }\end{array} \\
\text { Beta } \\
\end{array}$} & \multirow[b]{2}{*}{$\mathrm{t}$} & \multirow[b]{2}{*}{ Sig. } \\
\hline & & $\mathrm{B}$ & Std. Error & & & \\
\hline \multirow[t]{3}{*}{1} & (Constant) & 10,309 & 2,706 & & 3,810 &, 000 \\
\hline & $\begin{array}{l}\text { Pendidikan } \\
\text { Kewirausahaan }\end{array}$ & ,869 &, 118 & ,638 & 7,376 &, 000 \\
\hline & Lingkungan Keluarga & 052 & 104 & 043 & 498 & 620 \\
\hline
\end{tabular}

a. Dependent Variable: Minat Berwirausaha

Sumber : Data diolah peneliti (2017)

Untuk mengetahui nilai $\mathrm{T}$ tabel maka dapat

dihitung dengan perhitungan sebagai

berikut :

$$
\begin{aligned}
\mathrm{T} \text { tabel }= & \mathrm{t}(\alpha / 2: \mathrm{n}-\mathrm{k}-1) \\
& \mathrm{T}(0,025: 96-2-1)=
\end{aligned}
$$
1,985

Berdasarkan tabel di atas maka dapat diinterpretasikan masing-masing variabel $\mathrm{X}$ (independen) sebagai berikut :

a. Mengacu pada tabel di atas maka dapat diketahui nilai $\mathrm{T}$ hitung 7,376 > $\mathrm{T}$ tabel 1,985 dan nilai signifikansi 0,000
$<0,05$ maka dapat disimpulkan variabel pendidikan kewirausahaan berpengaruh signifikan terhadap minat berwirausaha.

b. Mengacu pada tabel di atas maka dapat diketahui nilai $\mathrm{T}$ hitung $0,498<\mathrm{T}$ tabel 1,985 dan nilai signifikansi 0,620 $>0,05$ maka dapat disimpulkan variabel lingkungan keluarga berpengaruh tidak signifikan terhadap minat berwirausaha.

\section{Uji F}

Tabel 1.11

Hasil Uji F

ANOVA ${ }^{\mathrm{a}}$

\begin{tabular}{|ll|r|r|r|r|r|}
\hline \multicolumn{2}{|l|}{ Model } & \multicolumn{1}{|c|}{$\begin{array}{c}\text { Sum of } \\
\text { Squares }\end{array}$} & df & Mean Square & F & \multicolumn{1}{c|}{ Sig. } \\
\hline 1 & Regression & 489,266 & 2 & 244,633 & 35,361 &, $000^{\mathrm{b}}$ \\
& Residual & 643,390 & 93 & 6,918 & & \\
& Total & 1132,656 & 95 & & & \\
\hline
\end{tabular}

a. Dependent Variable: Minat Berwirausaha

b. Predictors: (Constant), Lingkungan Keluarga, Pendidikan Kewirausahaan Sumber : Data diolah peneliti (2017) 
Untuk mengetahui nilai $\mathrm{F}$ tabel maka dapat dihitung dengan perhitungan sebagai berikut :

$$
\begin{aligned}
\mathrm{F} \text { tabel } & =\mathrm{F}(\mathrm{k}: \mathrm{n}: \mathrm{k}) \\
& =\mathrm{F}(2: 96-2) \\
& =\mathrm{F}(2: 94)=3,09
\end{aligned}
$$

Berdasarkan tabel di atas maka dapat diinterpretasikan pengaruh variabel $\mathrm{X}$ Koefisien Korelasi (independen) secara simultan terhadap variabel Y sebagai berikut : Dari tabel di atas dapat diketahui nilai $\mathrm{F}$ hitung 35,361 > 3,09 dan nilai signifikansi $0.000<0,05$ maka dapat disimpulkan variabel pendidikan kewirausahaan dan lingkungan keluarga berpengaruh signifikan terhadap minat berwirausaha secara simultan.

Tabel 1.12

Tingkat Keeratan Korelasi

\begin{tabular}{|c|c|}
\hline $\mathrm{R}$ & Tingkat keeratan \\
\hline $0,00-0,199$ & SangatLemah \\
\hline $0,20-0,399$ & Lemah \\
\hline $0,40-0,599$ & CukupKuat \\
\hline $0,60-0,799$ & Kuat \\
\hline $0,80-1,000$ & SangatKuat \\
\hline
\end{tabular}

Sumber: DuwiPriyatno (2016:83)

Nilai koefisien korelasi $r$ berkisar antara -1 sampai +1 atau $(-1<\mathrm{r}<1)$. Yang kriteria pemanfaatannya sebagai berikut :

a. Jika nilai $\mathrm{r}>1$, artinya telah terjadi hubungan yang linear positif, yaitu makin besar nilai variabel $X$, maka makin besar pula nilai variable $\mathrm{Y}$ atau sebaliknya.

b. Jika nilai $\mathrm{r}<0$, artinya telah terjadi hubungan yang linear negatif, yaitu makin kecil nilai variabel $X$ (independen), maka makin besar nilai variabel $\mathrm{Y}$ atau sebaliknya. c. Jika nilai $\mathrm{r}=0$, artinya tidak ada hubungan linear sempurna yaitu berupa garis lurus, sedangkan untuk nilai $r$ yang makin mengarah ke angka 0 maka garis tidak lurus.

d. Jika nilai $r=1$ atau $r=-1$, berarti telah terjadi hubungan linear sempurna yaitu berupa garis lurus, sedangkan untuk nilai $r$ yang makin mengarah ke angka 0 maka garis makin tidak tidak lurus.

Dalam konteks ini dapat diketahui niai determinasi pada tabel model summary sebagai berikut :

Tabel 1.13

Koefisien Korelasi

Correlations

\begin{tabular}{|ll|r|r|r|}
\hline & & $\begin{array}{c}\text { Pendidikan } \\
\text { Kewirausahaan }\end{array}$ & $\begin{array}{c}\text { Lingkungan } \\
\text { Keluarga }\end{array}$ & \multicolumn{1}{c|}{$\begin{array}{c}\text { Minat } \\
\text { Wirausaha }\end{array}$} \\
\hline Pendidikan Kewirausahaan & Pearson Correlation & 1 &, $428^{* *}$ &, $656^{* *}$ \\
& Sig. (2-tailed) & &, 000 &, 000 \\
& $\mathrm{~N}$ & 96 & 96 & 96 \\
\hline Lingkungan Keluarga & Pearson Correlation &, $428^{* *}$ & 1 &, $316^{* *}$ \\
& Sig. (2-tailed) &, 000 & 962 \\
& $\mathrm{~N}$ & 96 & 96 &, 002 \\
\hline Minat Wirausaha & Pearson Correlation &, $656^{* *}$ &, $316^{* * *}$ & 1 \\
& Sig. (2-tailed) &, 000 &, 002 & \\
& $\mathrm{~N}$ & 96 & 96 & 96 \\
\hline
\end{tabular}

**. Correlation is significant at the 0.01 level (2-tailed).

Sumber : Data Primer diolah peneliti (2017)

Berdasarkan data output di atas dapat ditarik kesimpulan dengan merujuk pada dasar pengambilan keputusan uji korelasi. Berdasarkan nilai signifikansi diketahui antara Pendidikan Kewirausahaan (X1) terhadap Minat Wirausaha (Y) nilai signifikansinya 0,656 , nilai koefisien korelasi diantara interval koefisien 0,60 - 
0,799 yang menyatakan tingkat hubungan positif yang "Kuat". Sedangkan koefisien korelasi antara Lingkungan Keluarga (X2) terhadap Minat Wirausaha (Y) sebesar

\section{Koefisien Determinasi}

0,316, nilai koefisien korelasi diantara interval koefisien $0,20-0,399$ yang menyatakan tingkat hubungan positif yang "Lemah".

Tabel 1.14

Model Summary

Model Summary

\begin{tabular}{|l|c|r|r|r|}
\hline Model & R & R Square & $\begin{array}{c}\text { Adjusted R } \\
\text { Square }\end{array}$ & $\begin{array}{c}\text { Std. Error of } \\
\text { the Estimate }\end{array}$ \\
\hline 1 &, $657^{\mathrm{a}}$ &, 432 &, 420 & 2,630 \\
\hline
\end{tabular}

a. Predictors: (Constant), Lingkungan Keluarga, Pendidikan

Kewirausahaan

Sumber : Data diolah peneliti (2017)

Dari tabel di atas maka dapat

diketahui nilai R Square adalah 0,420. Nilai ini berarti bahwa presentasi pengaruh variabel pendidikan kewirausahan dan

\section{PEMBaHASAN}

Mengacu pada tujuan penelitian diawal pembahasan yaitu untuk mengetahui pengaruh X1 dan X2 terhadap Y. Dari berbagai hasil uji data dan hipotesis menunjukan bahwa ada pengaruh dari kedua variabel tersebut. Pengaruh ini akan dijelaskan dipembahasan di bawah ini :

a. Pengaruh X1 terhadap Y

Mengacu pada hasil uji regresi $\beta_{1}$ dengan nilai 0,869 dan hasil uji $\mathrm{T}$ yaitu $\mathrm{T}$ hitung 7,376 $>\mathrm{T}$ tabel 1,985 dan nilai signifikansi $0,000<0,05$. Maka nilai $\mathrm{H}_{1}: \beta_{1} \neq 0$, artinya hipotesis $\mathrm{H}_{1}$ diterima atau $\mathrm{H}_{0}$ ditolak $\beta_{1} \neq 0$ dapat disimpulkan variabel pendidikan kewirausahaan berpengaruh signifikan terhadap minat berwirausaha.

Mengacu pada nilai $\beta_{1}$ maka dapat diindikasikan bahwa variabel pendidikan kewirausahaan memiliki pengaruh yang besar jika dibandingkan dengan variabel lingkungan keluarga.

b. Pengaruh X2 terhadap Y

Mengacu pada hasil uji regresi $\beta_{2}$ dengan nilai 0,052 dan hasil uji $\mathrm{T}$ yaitu $\mathrm{T}$ hitung $0,498<\mathrm{T}$ tabel 1,985 dan nilai signifikansi $0,620>0,05$. Maka nilai $\mathrm{H}_{1}: \beta_{2} \neq 0$, artinya hipotesis $\mathrm{H}_{1}$ diterima atau $\mathrm{H}_{0}$ ditolak $\beta_{2} \neq 0$ dapat disimpulkan variabel lingkungan keluarga berpengaruh tidak lingkungan keluarga terhadap minat berwirausaha adalah $43,2 \%$. Sisa nya adalah 56,8\% dipengaruhi variabel yang lain yang tidak diteliti dalam penelitian ini.

signifikan terhadap minat berwirausaha.

Mengacu pada nilai $\beta_{2}$ maka dapat diindikasikan bahwa variabel lingkungan keluarga memiliki pengaruh yang relatif kecil jika dibandingkan dengan variabel pendidikan kewirausahaan.

c. Pengaruh X1 dan X2 terhadap Y

Mengacu pada hasil uji regresi $\beta_{1}$ dengan nilai 0,869 dan $\beta_{2}$ dengan nilai 0,052 serta dan hasil uji $F$ yaitu $F$ hitung $35,361>3,09$ dan nilai signifikansi $0.000<0,05 . \quad$ Dari hipotesis diketahui $\mathrm{H}_{1}: \beta_{1}, \beta_{2} \neq 0$, artinya hipotesis $\mathrm{H}_{1}$ diterima atau $\mathrm{H}_{0}$ ditolak, maka dapat disimpulkan variabel pendidikan kewirausahaan dan lingkungan keluarga berpengaruh signifikan terhadap minat berwirausaha secara simultan.

Dilihat secara simultan kedua variabel ini berpengaruh relatif besar jika ingin meningkatkan minat berwirausaha pada mahasiswa maka perlu adanya kolaborasi antara pendidikan kewirausahaan dan lingkungan keluarga. Namun pendidikan kewirausahaanlah yang harus lebih ditingkatkan di Perguruan Tinggi Ilmu Ekonomi di Purwakarta. 


\section{KESIMPULAN}

Dalam penelitian ini beberapa pengujian telah dilakukan dalam menguji data dan hipotesis. Maka dari itu dapat ditarik kesimpulan sebagai berikut :

a. Terdapat pengaruh pendidikan kewirausahaan terhadap minat berwirausaha secara parsial.

\section{DAFTAR PUSTAKA}

Aritonang, Keke Taruli. 2013. Pengintegrasian Pendidikan Kewirausahaan melalui Pembelajaran Terpadu Berbagai Disiplin Ilmu. Jurnal Pendidikan Penabur, Vol. 12 (21), pp: 63-77.

Dedeng Abdul Gani A. 2012. Karakteristik Usaha dan Jiwa Wirausaha terhadap Kinerja Usaha pada Usaha Mikro dan Kecil (UMK) Keramik Plered. Jurnal Ekonomi dan Bisnis No. 1, Vol. 1 : 40-55.

Siswo Wiratno. 2012. Pelaksanaan Kewirausahaan di Perguruan Tinggi. Jurnal Pendidikan dan Kebudayaan Vol. 18, No. 4.

Ni Putu Ayu Aditya Wedayani dan I Gusti Ayu Ketut Giantari. 2016. Peran Pendidikan Kewirausahaan dalam Memediasi Pengaruh Norma Subyektif terhadap Niat Berwirausaha. E-Jurnal Manajemen Unud Vol. 5, No. 1 : 533-560.

Ramussen, Anders, dkk (2015). A Taxonomy of Entrepreneurship Education. The Danish Foundation for Entrepreneurship

Dewi, A.P dan Mulyatiningsih E. 2013. Pengaruh Pengalaman Pendidikan Kewirausahaan dan Keterampilan Kejuruan terhadap Motivasi Berwirausaha Siswa. Jurnal Pendidikan Vokasi, 3(2): h: 231-240.

Lestari, R.B. dan Wijaya, T. 2012.Pengaruh Pendidikan Kewirausahaan Terhadap Minat Berwirausaha Mahasiswa di STIE MDP, STMIK MDP, dan STIEMUSI. Jurnal Ilmiah STIE MD, 1(2): h:112-119.

Mopangga, Herwin. 2014. Faktor Determinan Minat Wirausaha Mahasiswa Fakultas Ekonomi dan Bisnis Universitas Negeri Gorontalo. Trikonomika, 13(1):h:78-90.

Putra, Rano Aditya. 2012. Faktor-Faktor Penentu Minat Mahasiwa Manajemen b. Terdapat pengaruh yang tidak signifikan lingkungan keluarga terhadap minat berwirausaha secara parsial.

c. Terdapat pengaruh variabel pendidikan kewirausahaan dan lingkungan keluarga terhadap minat berwirausaha secara simultan

Untuk Berwirasusaha (Studi Mahasiswa Manajemen FE Universitas Negeri Padang). Jurnal Manajemen, 1(1): h:3040.

Rochayati, Umi et al., 2013. Pengaruh Faktor Sosiodemografi, Sikap, dan Kontekstual terhadap Niat Berwirausaha Siswa. Jurnal Kependidikan, 43(2):h:154-163

Rosmiati, Rosmiati., Teguh Santosa, Junias., Munawar, Munawar. 2015.Sikap, Motivasi dan Minat Berwirausaha Mahasiswa. Jurnal Manajemen Dan Kewirausahaa, 17(1): h: 21

Suharti, Lieli dan Hani Sirine. 2011. FaktorFaktor yang Berpengaruh Terhadap Niat Kewirausahaan (Entrepreneurial Intention), (Studi Terhadap Mahasiswa Universitas Kristen Satya Wacana, Salatiga). Jurnal Manajemen dan Kewirausahaan, Vol. 13, (2), pp: 124134.

Sumarsono, Hadi. 2012. Faktor-Faktor yang Mempengaruhi Intensi WirausahaMahasiswa Universitas Muhammadiyah Ponogoro. Jurnal Manajemen,11(2): h:1-22.

Suryana, Yuyus dan Kartib Bayu. 2010. Kewirausahaan: Pendekatan Karakteristik Wirausahawan Sukses, Edisi Kedua. Jakarta: Kencana.

Utomo, Bambang Budi., Mashudi, dan Nuraini Asriati. 2014. Pengaruh Pendidikan Kewirausahaan dalam Keluarga dan di Sekolah terhadap Minat Berwirausaha dengan Mediasi Self-efficacy Siswa Kelas XI. Jurnal Pendidikan dan Pembelajaran, Vol. 3 (4), pp: 1-15.

Z. Heflin Frinces. 2010. Pentingnya Profesi Wirausaha di Indonesia. Jurnal Ekonomi dan Pendidikan. Vol. 7, No. 1 : 34-57. 